\title{
Postnatal Development of Membrane Excitability in Taste Cells of the Mouse Vallate Papilla
}

\author{
Albertino Bigiani, ${ }^{1}$ Rosella Cristiani, ${ }^{2}$ Francesca Fieni, ${ }^{1}$ Valeria Ghiaroni, ${ }^{1}$ Paola Bagnoli, ${ }^{2}$ and \\ Pierangelo Pietra ${ }^{1}$ \\ 1Dipartimento di Scienze Biomediche, Sezione di Fisiologia, Università di Modena e Reggio Emilia, 41100 Modena, Italy, \\ and 2Dipartimento di Fisiologia e Biochimica "G. Moruzzi," Università di Pisa, 56127 Pisa, Italy
}

The mammalian peripheral taste system undergoes functional changes during postnatal development. These changes could reflect age-dependent alterations in the membrane properties of taste cells, which use a vast array of ion channels for transduction mechanisms. Yet, scarce information is available on the membrane events in developing taste cells. We have addressed this issue by studying voltage-dependent $\mathrm{Na}^{+}, \mathrm{K}^{+}$, and $\mathrm{Cl}^{-}$currents $\left(I_{\mathrm{Na}}, I_{\mathrm{K}}\right.$, and $I_{\mathrm{Cl}}$, respectively) in a subset of taste cells (the so-called "Na/OUT" cells, which are electrically excitable and thought to be sensory) from mouse vallate papilla. Voltage-dependent currents play a key role during taste transduction, especially in the generation of action potentials. Patch-clamp recordings revealed that $I_{\mathrm{Na}}, I_{\mathrm{K}}$, and $I_{\mathrm{Cl}}$ were expressed early in postnatal development. However, only $I_{K}$ and $I_{\mathrm{Cl}}$ densities increased significantly in developing Na/OUT cells.
Consistent with the rise of $I_{\mathrm{K}}$ density, we found that action potential waveform changed markedly, with an increased speed of repolarization that was accompanied by an enhanced capability of repetitive firing. In addition to membrane excitability changes in putative sensory cells, we observed a concomitant increase in the occurrence of glia-like taste cells (the so called "leaky" cells) among patched cells. Leaky cells are likely involved in dissipating the increase of extracellular $\mathrm{K}^{+}$during action potential discharge in chemosensory cells. Thus, developing taste cells of the mouse vallate papilla undergo a significant electrophysiological maturation and diversification. These functional changes may have a profound impact on the transduction capabilities of taste buds during development.

Key words: development; taste cells; membrane excitability; gustatory; patch clamp; vallate papilla
Electrophysiological recordings from gustatory nerves have shown that in many mammalian species the peripheral taste system undergoes functional changes during postnatal development. For example, neural responses to substances like sugars and sodium ions mature over several weeks after birth (Mistretta and Hill, 1995; Stewart et al., 1997). In addition to morphogenetic events, it is likely that these functional modifications may arise from age-dependent changes in the expression and regulation of transduction mechanisms at the level of taste cells. Taste cells use a vast array of ion channels and receptors to transduce chemical signals into afferent nerve discharge (Lindemann, 1996); changes in the expression and regulation of these membrane components would have obvious repercussions on the functionality of the taste system during development.

Voltage-gated ion channels play a key role in taste transduction, especially in the events downstream of the early interaction with chemical stimuli (Herness and Gilbertson, 1999). Taste cells in adult mammals are electrophysiologically heterogeneous, and many of them are electrically excitable by possessing voltagegated $\mathrm{Na}^{+}$and $\mathrm{K}^{+}$channels, which, as in neurons, underlie action potential generation (Roper, 1983; Kinnamon and Roper, 1987;

Received July 26, 2001; revised Sept. 27, 2001; accepted Oct. 19, 2001.

This study was supported by Ministero dell'Università e della Ricerca Scientifica e Tecnologica (MURST, Cofin 1998 and 2000 to A.B. and P.B.) and by Banca Popolare dell'Emilia Romagna (scholarship to F.F.).We thank Fausto Vaccari and Giuseppe Nespoli (Università di Modena e Reggio Emilia) for their excellent technical assistance.

Correspondence should be addressed to Dr. Albertino Bigiani, Dipartimento di Scienze Biomediche, Sezione di Fisiologia, Università di Modena e Reggio Emilia, via Campi 287, 41100 Modena, Italy. E-mail: bigiani@unimo.it.

Copyright (C) 2002 Society for Neuroscience $0270-6474 / 02 / 220493-12 \$ 15.00 / 0$
Chen et al., 1996). Action potential firing appears to be one important step in the transduction and signaling of sensory information in taste buds. For example, the frequency of spike discharge is related to the concentration of certain stimuli (Gilbertson et al., 1992; Cummings et al., 1993). In addition, membrane depolarization during action potential seems to be necessary to activate $\mathrm{Ca}^{2+}$ channels for neurotransmitter release underlying signal transfer to afferent nerves (Béhé et al., 1990; Furue and Yoshii, 1997). Finally, action potentials may be used for intercellular communications through gap junctions inside the taste buds (Bigiani and Roper, 1995).

The pattern and time course of the expression of voltage-gated $\mathrm{Na}^{+}$and $\mathrm{K}^{+}$channels underlying membrane excitability is known to change during development in neurons and sensory cells (Gao and Ziskind-Conhaim, 1998; Kros et al., 1998). However, in taste cells of the rat fungiform papillae, Kossel et al. (1997) established that voltage-gated $\mathrm{Na}^{+}$and $\mathrm{K}^{+}$currents do not change during postnatal development. In this paper, we have reexamined the issue of membrane excitability in developing taste cells by studying with the patch-clamp technique the electrophysiological properties of a subset of taste cells from the mouse vallate papilla (the so called "Na/OUT" cells, which are thought to be sensory). Unlike findings in rat, our data show that the density of voltage-gated $\mathrm{K}^{+}$and $\mathrm{Cl}^{-}$currents increases significantly in these cells with the age of the animals. Moreover, we found that the electrophysiological heterogeneity of taste cells in adult animals is set during postnatal development. Thus, our data indicate that postnatal changes in ionic currents of rat and mouse taste sensory cells are very different. As a whole, our findings suggest that in the mouse the functional maturation of the pe- 
ripheral taste system might rely, at least in part, on alterations of membrane excitability of taste cells.

\section{MATERIALS AND METHODS}

Tissue preparation. C57BL/6J mice were used. Vallate taste buds were isolated with an enzymatic-mechanical procedure (Bigiani, 2001). Mice were deeply anesthetized with $\mathrm{CO}_{2}$, followed by dislocation of cervical vertebrae. Tongues were rapidly removed and placed in Tyrode solution containing (in mM): $140 \mathrm{NaCl}, 5 \mathrm{KCl}, 2 \mathrm{CaCl}_{2}, 1 \mathrm{MgCl}_{2}, 10 \mathrm{HEPES}, 10$ glucose, $10 \mathrm{Na}$ pyruvate, $\mathrm{pH} 7.4$ with $\mathrm{NaOH}$. Two milligrams of elastase (Worthington Biochemical Corporation, Freehold, NJ), and $2 \mathrm{mg}$ of dispase (grade II; Boehringer Mannheim, Mannheim, Germany) in 1.0 $\mathrm{ml}$ of Tyrode solution were injected (0.2-0.4 $\mathrm{ml}$ per tongue) between the lingual epithelium and muscle layer. Tongues were incubated in $\mathrm{Ca}^{2+}$ free Tyrode solution at $30^{\circ} \mathrm{C}$ for $\sim 15-70 \mathrm{~min}$, depending on the age of the animal (longer incubation times were required for juveniles) (Kossel et al., 1997). After incubation, the lingual epithelium was peeled free from the underlying tissue, pinned serosal side up in a Sylgard-lined Petri dish, and incubated in $\mathrm{Ca}^{2+}$-free Tyrode solution for $\sim 5-20 \mathrm{~min}$. Vallate taste buds were removed by gentle suction with a fire-polished pipette and plated onto glass slides coated with Cell-Tak (Collaborative Research, Bedford, MA). Drugs were dissolved in modified Tyrode solutions to maintain osmolarity. All chemicals were from Sigma (St. Louis, MO), except tetrodotoxin (TTX; Alomone, Jerusalem, Israel).

Recording techniques. Membrane currents of single cells in isolated taste buds were studied by whole-cell patch clamp (Hamill et al., 1981) with use of an Axopatch 1D amplifier (Axon Instruments, Foster City, CA). Signals were recorded and analyzed using a 486-based computer equipped with Digidata 1200 data acquisition system and pClamp6 software (Axon Instruments).

Patch pipettes were made from soda lime glass capillaries (Baxter Scientific Products, McGaw Park, IL) on a vertical puller (model PB-7, Narishige, Tokyo, Japan). For voltage-clamp recordings, the pipette solution contained (in mM): $120 \mathrm{KCl}, 1 \mathrm{CaCl}_{2}, 2 \mathrm{MgCl}_{2}, 10 \mathrm{HEPES}, 11$ EGTA, 2 ATP, 0.4 GTP, pH 7.3 with KOH. For current-clamp recordings, $\mathrm{KCl}$ was replaced by an equal concentration of potassium gluconate. Pipette resistances were 3-5 M $\Omega$ when filled with intracellular solution. Leakage and capacitive currents were not subtracted from currents under voltage clamp, and all voltages have been corrected for liquid junction potential (LJP) $(\sim 4 \mathrm{mV}$ for $\mathrm{KCl}$ pipette solution and $\sim 10 \mathrm{mV}$ for potassium gluconate pipette solution) (Neher, 1992). Input resistance and cell membrane capacitance were measured as described previously (Bigiani, 2001).

Immunohistochemical procedures. As a morphological marker for the functional maturation of taste buds, we used immunocytochemistry to determine the expression of $\alpha$-gustducin, a taste-specific G-protein (Wong et al., 1996; Ming et al., 1999). Whole mounts of the vallate papilla, obtained after enzymatic treatment and peeling (Kim and Roper, 1995), were fixed with $4 \%$ paraformaldehyde in $0.1 \mathrm{M}$ phosphate buffer $(\mathrm{PB})$ for $3 \mathrm{hr}$ at room temperature. Then, they were incubated for $3 \mathrm{~d}$ at $40^{\circ} \mathrm{C}$ with a primary antibody (G $\alpha$ gust, 1:100; Santa Cruz Biotechnology, Santa Cruz, CA) in $0.1 \mathrm{M}$ PB containing $5 \%$ normal goat serum and $0.5 \%$ Triton X-100. After they were rinsed in $0.1 \mathrm{M} \mathrm{PB}$, whole-mount preparations were immersed in a secondary antibody, a fluorescein isothiocyanate (FITC)-conjugated anti-rabbit IgG (1:100; Vector Laboratories, Burlingame, CA) in $0.1 \mathrm{M} \mathrm{PB}$ for $12 \mathrm{hr}$ at $40^{\circ} \mathrm{C}$. Specificity of the immune reaction was assessed according to previous studies (Boughter et al., 1997; Cho et al., 1998). Immunofluorescence was examined using a Nikon TE 800 fluorescence microscope and also with a Bio-Rad Laser Scanning Microscope Radiance Plus (Bio-Rad, Hemstead Herts, UK). Electronic images from the confocal microscope were processed using Adobe Photoshop 5.0 (Adobe Systems, Mountain View, CA). Immunocytochemical data were analyzed according to previous studies (Boughter et al., 1997; Cho et al., 1998).

Statistical analysis. Results are presented as means \pm SEM. Data comparisons were made with a two-tailed independent $t$ test, and significance level was taken as $p<0.05$. Distribution of ion current magnitude was displayed in the form of a box plot. In this plot, boxes show the middle half of the data (approximately the 25 th and 75 th percentiles) and the horizontal line marks the median, whereas the "whiskers" extending from the top and bottom of the boxes show the main body of the data. Outliers or extreme values are plotted individually with circles.
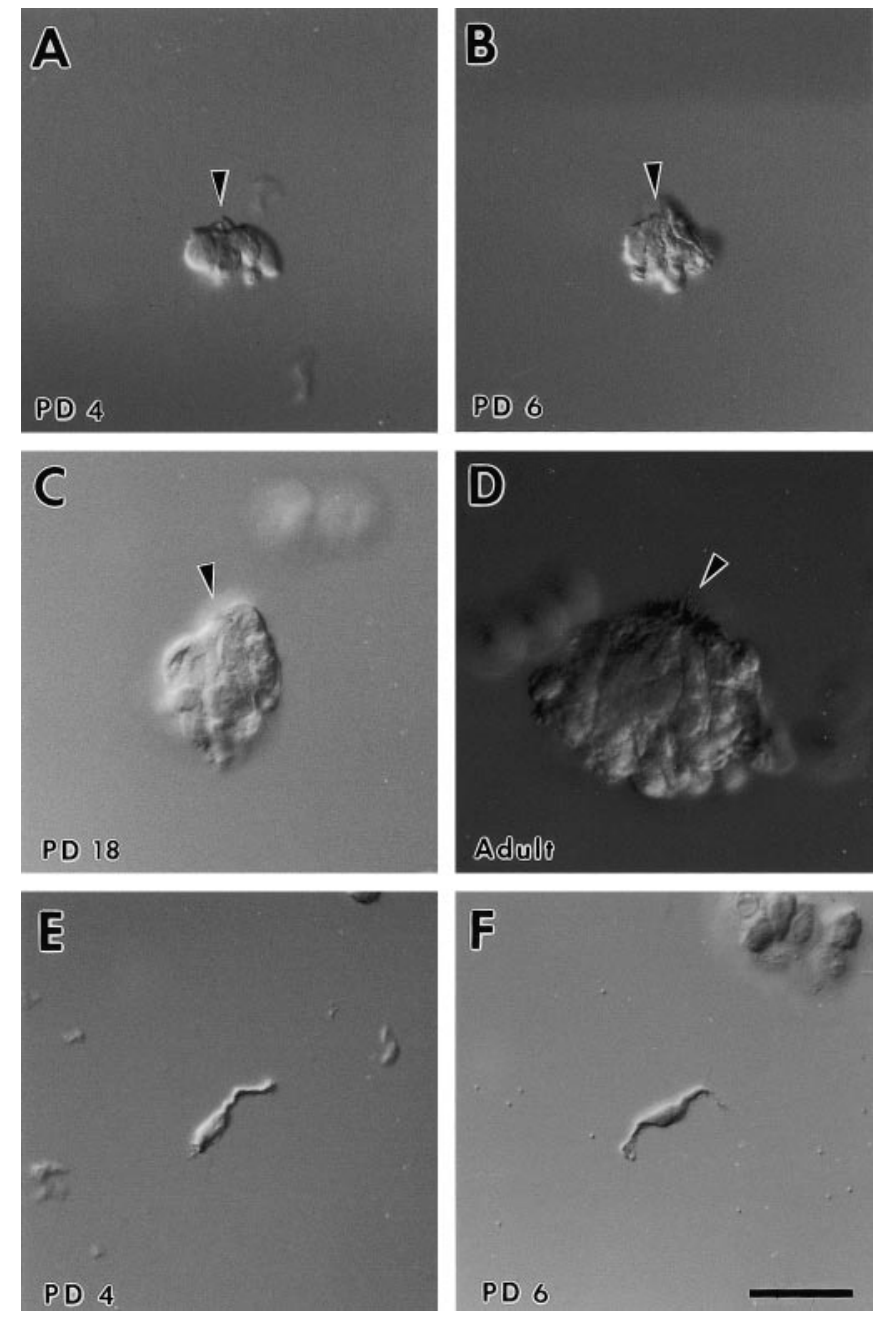

Figure 1. Development of mouse vallate taste buds. $A-D$, Differential interference contrast photomicrographs depicting taste buds isolated from the mouse vallate papilla at different postnatal ages. Taste buds increase in size during development, which is most likely attributable to an increase in the number of cells per bud. $E, F$, Isolated taste cells from juvenile vallate papilla. Note the cellular processes. $P D$, Postnatal day. Arrowhead indicates apical pole. Scale bar, $25 \mu \mathrm{m}$.

\section{RESULTS}

\section{Isolated taste buds during postnatal development}

Taste bud formation and taste cell differentiation occur postnatally in the mouse (Nolte and Martini, 1992; Cooper and Oakley, 1998). After isolation, taste cells typically remained aggregated at their apical poles, resembling a taste bud (Fig. $1 A-D)$. However, partially disaggregated taste buds and sometimes isolated taste cells (Fig. $1 E, F$ ) could be obtained during the dissociation procedure (Béhé et al., 1990). Isolated taste cells were more commonly found when taste tissue was dissociated from mouse pups (Fig. $1 E, F$ ). The presence of solitary taste cells during the first week of postnatal life has been documented recently in the rat vallate papilla (Sbarbati et al., 1999). Taste buds could be isolated reliably at postnatal day 4 (PD 4), although the size was smaller as compared with buds obtained from older animals (Fig. 1). This was consistent with earlier histological studies on vallate taste buds of the rat, indicating that taste bud size increases during postnatal development (Hosley and Oakley, 1987). With mice 
younger than PD4, identification of isolated taste buds proved to be difficult, and the preparation yield was poor.

Using the patch-clamp technique, we were able to study the electrophysiological properties of single cells in taste buds isolated from mouse vallate papilla as early as PD 4. Stable recordings were obtained from a total of 470 cells, and data were referred to the following age groups: PD 4-7; PD 8-14; PD 15-21; PD 22-28; and PD > 28 (adults).

\section{Functional populations of taste cells during development}

Taste cells in adult mammals are functionally heterogeneous as to the expression of voltage-dependent ion currents (Akabas et al., 1990; Béhé et al., 1990; Chen et al., 1996; Kossel et al., 1997; Bigiani, 2001). Accordingly, in a first series of experiments we studied the membrane currents elicited in mouse taste cells by depolarizing voltage steps from a reference holding potential of $-84 \mathrm{mV}$ (LJP corrected). In this experimental condition we were able to identify three main functional groups of taste cells in the vallate papilla of the adult mouse.

Most of the recorded cells ( $57 \%$; 82 of 145 cells) were characterized by the presence of voltage-gated, TTX-sensitive $\mathrm{Na}^{+}$currents $\left(I_{\mathrm{Na}}\right)$ and voltage-dependent outward currents $\left(I_{\text {out }}\right)$ (Fig. $\left.2 A\right)$. These cells were named Na/OUT cells, according to Bigiani (2001). Pharmacological dissection revealed that $I_{\text {out }}$ was mediated by potassium and chloride ions. However, as indicated by data reported in Figure 3, the relative proportion of $\mathrm{K}^{+}$ currents and $\mathrm{Cl}^{-}$currents to $I_{\text {out }}$ was highly variable. In some cells, tetraethylammonium (TEA), a potassium channel blocker (Rudy, 1988; Castle et al., 1989), totally abolished the outward currents (Fig. $3 A$ ), whereas in other cells it affected these currents only partially (Fig. 3B). Conversely, 4,4'-diisothiocyanostilbene2,2'-disulfonic acid (DIDS), a known $\mathrm{Cl}^{-}$conductance blocker in taste cells (Taylor and Roper, 1994; Herness and Sun, 1999), did not affect the outward currents in some cells (data not shown) or partially affected them in others (Fig. 3C).

A second group of taste cells ( $12 \%$; 17 of 145 cells) was characterized by the presence of voltage-dependent outward currents only (Fig. $2 B$ ). For this reason, they were named OUT cells (Bigiani, 2001). Outward currents in these cells were predominantly carried by potassium ions (data not shown).

Finally, $\sim 32 \%$ (46 of 145 cells) of taste cells in the vallate taste buds of adult animals displayed strong leakage currents (Fig. 2C). Accordingly, they were named leaky cells. As demonstrated recently (Bigiani, 2001), leaky cells are endowed with a conspicuous resting potassium conductance (responsible for the leakage currents), whereas voltage-dependent conductances are negligible.

After establishing the functional subsets of taste cells in the adults, we addressed the following issue: do these subsets occur also in developing taste buds? To determine this, we recorded membrane currents from taste cells as early as PD 4. Electrophysiologically identified cells were assigned to the functional subsets described above and pooled according to five age groups (PD 4-7; PD 8-14; PD 15-21; PD 22-28; PD > 28). Patch-clamp recordings demonstrated that Na/OUT cells, OUT cells, and leaky cells could be identified at all ages (Fig. 4). However, when we evaluated the relative percentage of each cell type, we found that their occurrence changed significantly during postnatal development. In particular, leaky cells were almost absent during the first 2 weeks; Na/OUT cells and OUT cells were, as a whole, the most frequent in this period (Fig. 4). At the third postnatal week, that is, 1 week before weaning in the mouse, the percentage
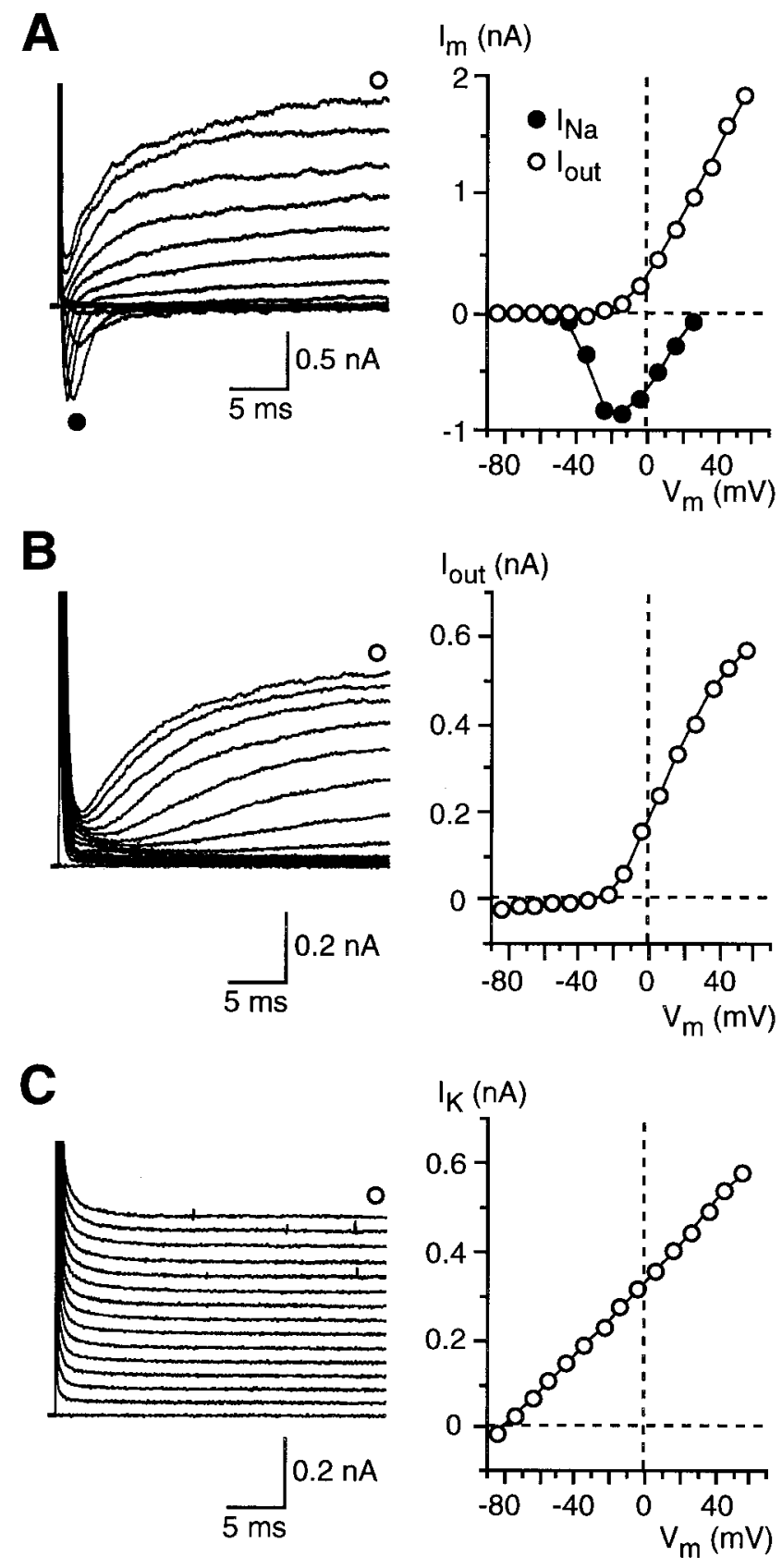

Figure 2. Membrane currents in three different populations of taste cells from vallate papilla of adult mice. Cells were held at $-84 \mathrm{mV}$ and stepped in $10 \mathrm{mV}$ increments from -74 to $+56 \mathrm{mV}$. $A$, Na/OUT cells were characterized by voltage-dependent inward $\mathrm{Na}^{+}$currents $\left(I_{\mathrm{Na}}\right)$ and outward currents $\left(I_{\text {out }}\right)$ carried by $\mathrm{K}^{+}$and $\mathrm{Cl}^{-}$. As shown by the currentvoltage $(I-V)$ relationships on the right, $I_{\mathrm{Na}}$ and $I_{\text {out }}$ typically activated at approximately $-50 \mathrm{mV}$ and approximately $-20 \mathrm{mV}$, respectively. $I_{\mathrm{m}}$, Membrane currents. $B$, OUT cells possessed only $I_{\text {out }}$ currents, which were carried predominantly by $\mathrm{K}^{+}$. Outward currents activated at a voltage similar to the one observed in $\mathrm{Na} / \mathrm{OUT}$ cells. $C$, Leaky cells were characterized by the presence of a conspicuous leakage current carried by $\mathrm{K}^{+}\left(I_{\mathrm{K}}\right)$ that was almost negligible in the other two groups of cells. In all $I-V$ plots, outward currents were measured at the end of the $30 \mathrm{msec}$ voltage pulses. $V_{\mathrm{m}}$, Membrane potential.

of leaky cells increased considerably, approaching the value found in the adult vallate papilla (Fig. 4). Thus, there was a rearrangement in the relative occurrence of the functional subsets of taste cells in the vallate taste buds during postnatal development. 


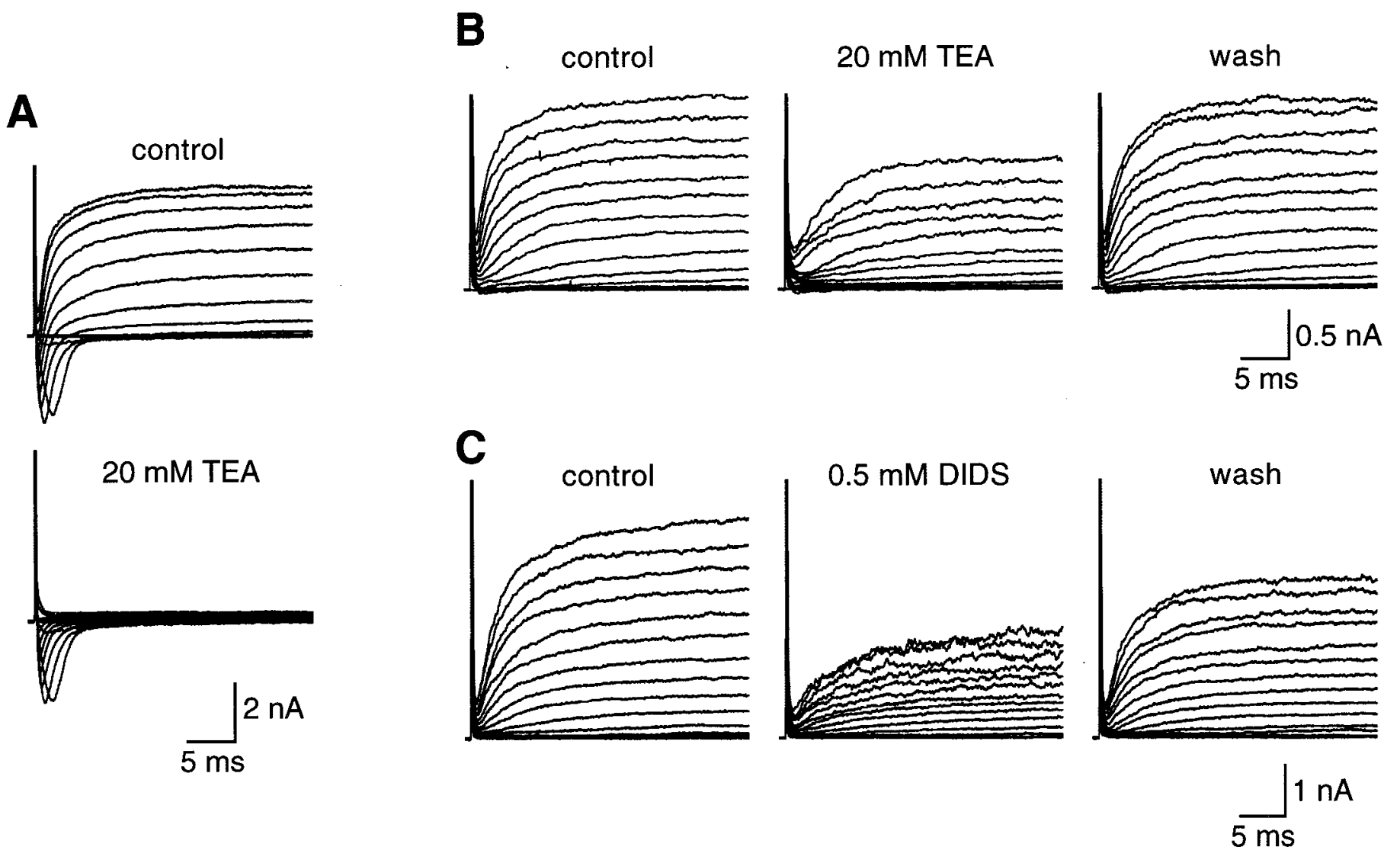

Figure 3. Contribution of $\mathrm{K}^{+}$currents and $\mathrm{Cl}^{-}$currents to the voltage-dependent outward currents in Na/OUT cells from adult mice. Membrane currents were elicited by a series of $30 \mathrm{msec}$ depolarizing pulses between $-74 \mathrm{mV}$ and $+76 \mathrm{mV}$, in $10 \mathrm{mV}$ increments, from a holding potential of -84 $\mathrm{mV} . A$, In some cells, outward currents were carried almost exclusively by $\mathrm{K}^{+}$ions, as indicated by their high sensitivity to TEA. In this example, outward currents recorded in regular Tyrode solution (control) were totally abolished by $20 \mathrm{~mm}$ TEA. Note that TEA did not affect voltage-gated Na ${ }^{+}$currents (downward deflections in the current records). $B$, In other cells, on the contrary, $20 \mathrm{~mm}$ TEA blocked the outward currents only partially, indicating that TEA-insensitive currents occurred in taste cell membranes. $C$, Consistent with the partial block by TEA was the finding that DIDS affected outward currents. In this cell, outward currents recorded in regular Tyrode solution (control) were partially abolished by 0.5 mM DIDS. The effect was reversible, as indicated by the recovery of the currents during washout (wash). In $B$ and $C$, recordings were obtained in the presence of $1 \mu \mathrm{M}$ TTX to block voltage-gated $\mathrm{Na}^{+}$currents.

Mammalian taste cells are structurally heterogeneous, and different cell morphotypes have been identified, such as elongated cells (subdivided in type I, type II, and type III cells) and round basal cells (Roper, 1989; Lindemann, 1996). At the moment, we do not have data on the structural features of the taste cells belonging to the functional subsets identified in mouse vallate papilla (that is, Na/OUT cells, OUT cells, and leaky cells). Further studies involving correlation of electrophysiological recordings with cell identification at the electron microscopic level are required to establish whether the functional subsets correspond to any of the known morphotypes.

\section{Development of membrane properties in $\mathrm{Na}$ /OUT cells}

Several observations suggest that taste cells capable of firing action potentials are involved in chemotransduction. Action potential discharges are regularly recorded from taste cells during chemostimulation in mammals (Béhé et al., 1990; Avenet and Lindemann, 1991; Gilbertson et al., 1992; Cummings et al., 1993; Furue and Yoshii, 1997; Ohtubo et al., 2001). Given the presence of voltage-gated $\mathrm{Na}^{+}$currents, Na/OUT cells are able to fire action potentials (see below). Thus, it is conceivable that $\mathrm{Na}$ / OUT cells, or at least part of them, represent sensory cells. For this reason, we focused our attention on the electrophysiological properties of these cells by addressing the following question: do the membrane properties of $\mathrm{Na} / \mathrm{OUT}$ cells change during postnatal development? The low occurrence of OUT cells throughout development (Fig. 4) prevented us from performing a detailed analysis of their electrophysiological properties. A similar argument holds also for leaky cells, which display a very low incidence during early development (Fig. 4).

\section{Development of passive membrane properties}

In the whole-cell patch-clamp configuration, two parameters are commonly used to characterize the passive membrane properties of excitable cells: the zero-current potential $\left(V_{0}\right.$, an estimation of the cell resting potential) and the input resistance $\left(R_{\text {in }}\right.$, an estimation of the cell membrane resistance) (Barry and Lynch, 1991; Bigiani et al., 1996). In Na/OUT cells, these electrophysiological parameters changed during postnatal development (Fig. 5). Taste cells from young animals displayed a significantly less negative $V_{0}$ than adults (Fig. 5, top). Estimation of the resting potential with the patch-clamp technique might require significant corrections because of shunt to ground by the seal resistance (Barry and Lynch, 1991). Age-related variations of seal resistances could have affected $V_{0}$ measurements. However, we did not detect any significant variations in seal resistance when patch electrodes 


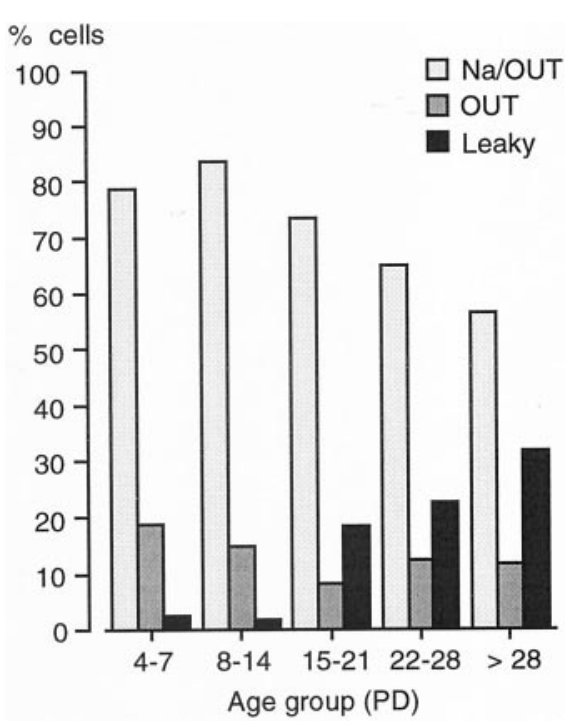

Figure 4. Electrophysiological subsets of taste cells in the mouse vallate papilla during postnatal development. Histograms represent the percentage of $\mathrm{Na} / \mathrm{OUT}$ cells, OUT cells, and leaky cells for five age groups $(P D$, postnatal day). The occurrence of leaky cells changed significantly with the age of the animals. Total number of tested cells: 85 (PD 4-7); 61 (PD 8-14); 49 (PD 15-21); 40 (PD 22-28); 145 (PD > 28).

were applied to taste cells of different age groups (data not shown). Although the actual resting potential of Na/OUT cells might be more negative than that measured in our experimental conditions, the change in $V_{0}$ during development was indicative of variations in the "resting" properties of these cells.

$R_{\text {in }}$ was evaluated as the slope resistance of the linear currentvoltage relationship at a membrane potential of $-84 \mathrm{mV}$ (corresponding to our standard holding potential corrected for LJP). Concomitantly with $V_{0}$ changes, we observed also a decrease in $R_{\text {in }}$ during development (Fig. 5, middle), although the differences between age groups were not statistically significant.

Finally, we also measured the cell membrane capacitance $\left(C_{\mathrm{m}}\right)$ of Na/OUT cells. $C_{\mathrm{m}}$ is directly related to the cell surface area and can give an estimation of the extension of the cell membrane in single as well as in coupled taste cells (Bigiani and Roper, 1993). As shown in Figure 5 (bottom), $C_{\mathrm{m}}$ did not differ significantly among the various age groups. This suggests that $\mathrm{Na} / \mathrm{OUT}$ cells reach their mature surface size early in development. A similar finding was obtained also by Kossel et al. (1997) for taste cells of rat fungiform papillae.

\section{Development of voltage-dependent currents}

Electrophysiological recordings demonstrated that Na/OUT cells were already present in the vallate papilla from early developmental stages (Fig. 4). As reported above, these cells are endowed with voltage-gated $\mathrm{Na}^{+}$currents $\left(I_{\mathrm{Na}}\right)$ and voltage-dependent outward currents $\left(I_{\text {out }}\right)$ mediated by $\mathrm{K}^{+}$and $\mathrm{Cl}^{-}$(Figs. 2, 3). In other excitable cells, such as neurons and sensory cells, these voltage-dependent currents are known to undergo significant changes during development. In particular, variations in current amplitude, which affects profoundly membrane excitability, are well documented (Baraban and Lothman, 1994; Gao and Ziskind-Conhaim, 1998; Kros et al., 1998). Thus, we addressed the following issue: does the amplitude of voltage-dependent currents change in $\mathrm{Na} / \mathrm{OUT}$ cells during postnatal development? First we analyzed $I_{\mathrm{Na}}$. Figure $6 \mathrm{~A}$ shows the $I-V$ plots for $I_{\mathrm{Na}}$
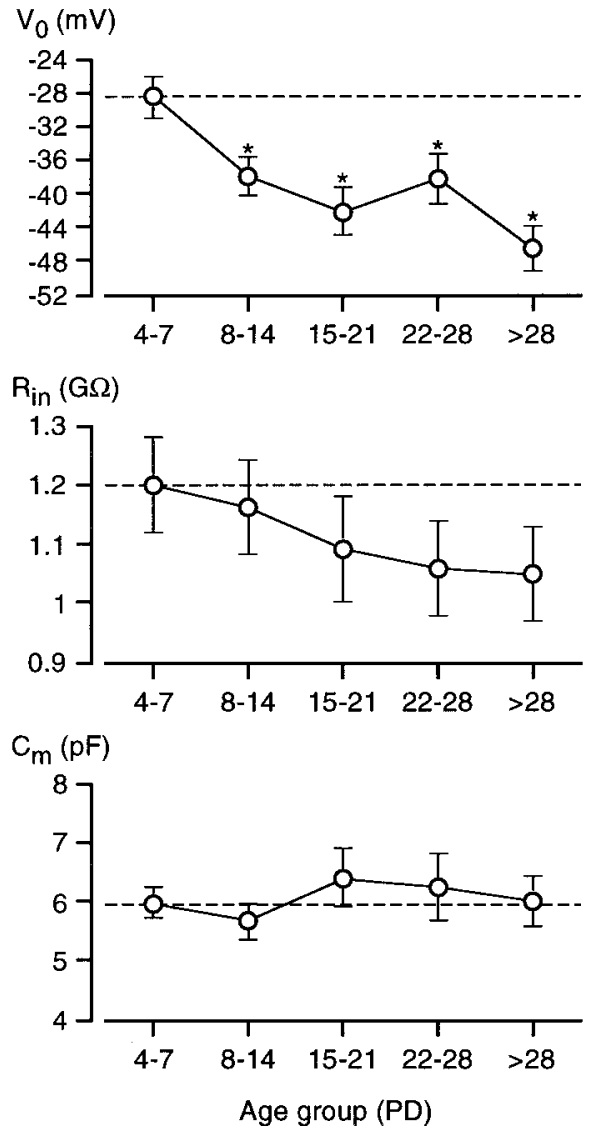

Figure 5. Zero-current potential $\left(V_{0}\right)$, input resistance $\left(R_{\text {in }}\right)$, and membrane capacitance $\left(C_{\mathrm{m}}\right)$ of $\mathrm{Na} / \mathrm{OUT}$ cells during postnatal development. Cells were grouped into five age classes, and measurements of each electrophysiological parameter were averaged within each group. $V_{0}$ changed significantly during development, becoming more negative $(n=$ $40 / 43 / 20 / 20 / 35$; error bars represent SEM). $R_{\text {in }}$ decreased in older animals, but changes were not significant ( $n=41 / 43 / 19 / 18 / 38$ ). Finally, there was not a significant change in $C_{\mathrm{m}}$ and, therefore, in membrane surface area of single vallate taste cells during development ( $n=41 / 44 / 20 / 17 / 37)$. Asterisks indicate significant differences. $P D$, Postnatal day.

evaluated in taste cells belonging to different age groups (PD 4-7, PD 15-21, PD > 28). In the adults ( PD > 28), $I_{\mathrm{Na}}$ activated at approximately $-50 \mathrm{mV}$ and peaked at approximately $-20 \mathrm{mV}$. There was not a significant change of these biophysical characteristics during development (Fig. 6A). Moreover, the average peak value of $I_{\mathrm{Na}}$ did not show any significant pattern of variation during development (PD 4-7: $-609 \pm 136 \mathrm{pA}, n=45$; PD 8-14: $-762 \pm 144, n=42$; PD 15-21: $-558 \pm 144, n=22$; PD 22-28: $-765 \pm 235, n=18$; PD $>28:-745 \pm 113, n=49)$. These results were in agreement with those reported for taste cells of rat fungiform papillae (Kossel et al., 1997).

In our experiments, $\mathrm{Na}^{+}$currents were not studied in isolation. However, it is unlikely that the kinetics of outward currents could influence the activation threshold and peak magnitude of $I_{\mathrm{Na}}$. As shown by Figure $7 B$, outward currents activate at approximately $-20 \mathrm{mV}$ and do not reach a sizeable magnitude until $\sim 0 \mathrm{mV}$.

Although the average peak value for $I_{\mathrm{Na}}$ did not change significantly during development, the analysis of the distribution of $I_{\mathrm{Na}}$ magnitude among cells revealed a noticeable skewness. In Figure $6 B$, peak $I_{\mathrm{Na}}$ values are displayed in the form of a box plot for young (PD 4-7), preweaning (PD 15-21), and adult $(\mathrm{PD}>28$ ) mice. As indicated by the plot, the range of $I_{\mathrm{Na}}$ magnitude was 
A

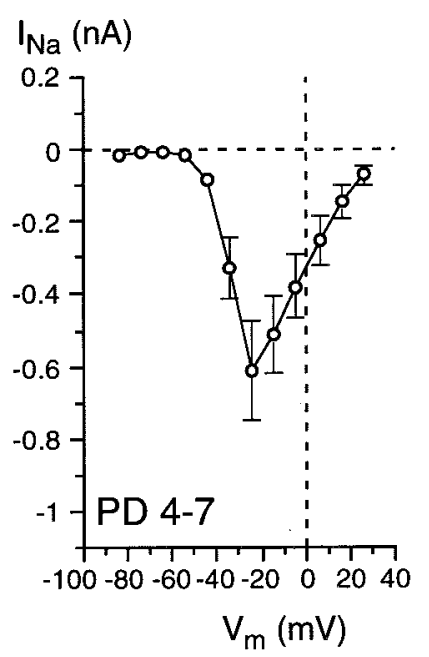

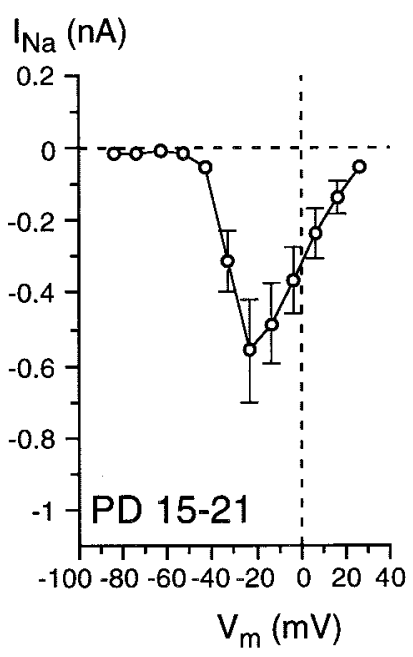

B

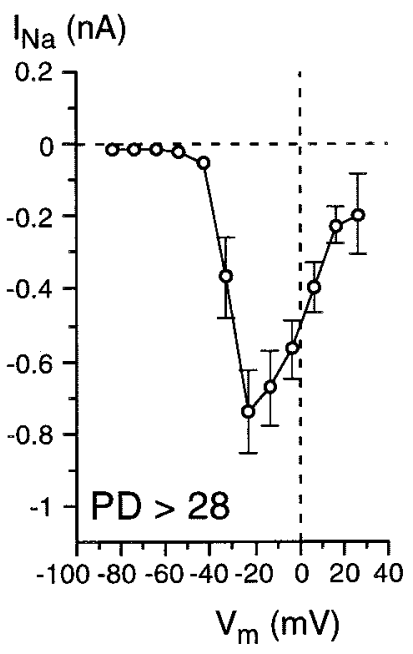

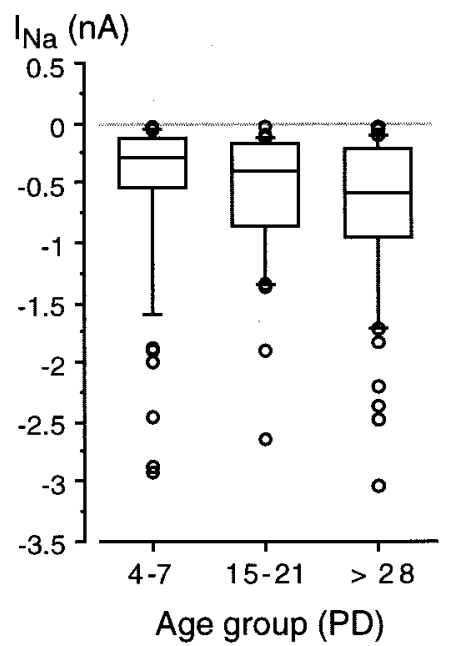

Figure 6. Voltage-gated $\mathrm{Na}^{+}$currents $\left(I_{\mathrm{Na}}\right)$ in Na/OUT cells during postnatal development. $A$, Current-voltage relationships. Cells were pooled into three age groups $(P D 4-7, P D 15-21$, and $P D>28)$, and $I_{\mathrm{Na}}$ values for each membrane potential $\left(V_{\mathrm{m}}\right)$ were averaged within each group $(n=44 / 23 / 44)$. $I_{\mathrm{Na}}$ activated at approximately $-50 \mathrm{mV}$ and peaked at approximately $-20 \mathrm{mV}$ in all age groups. There was no significant pattern of variation for the average maximum value of $I_{\mathrm{Na}}$ during development. The holding potential was $-84 \mathrm{mV}$. $P D$, Postnatal day. $B$, Peak value distribution of $I_{\mathrm{Na}}$ displayed in the form of a box plot (see Materials and Methods for details) for three age groups ( $P D 4-7, P D 15-21$, and $P D>28)$. Note that the median (the horizontal line in the middle of each box) increases during development, whereas the data range does not. $n=61(P D 4-7), 36(P D 15-21), 67(P D>$ 28).

A

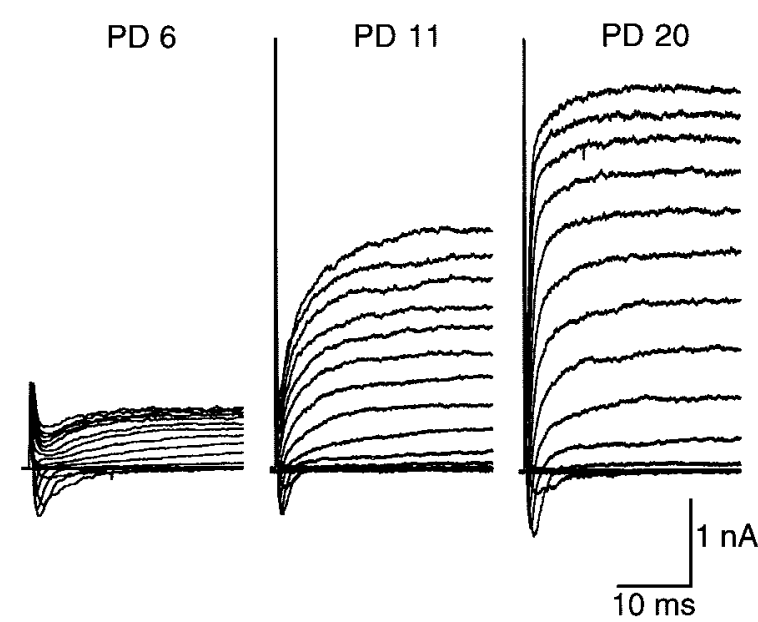

B

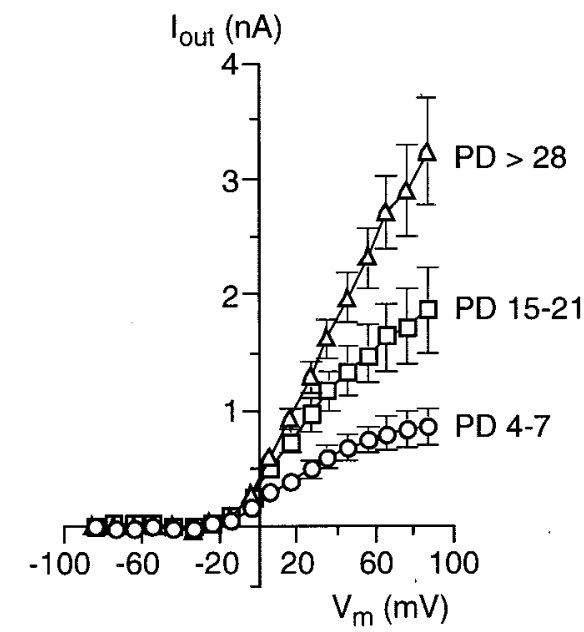

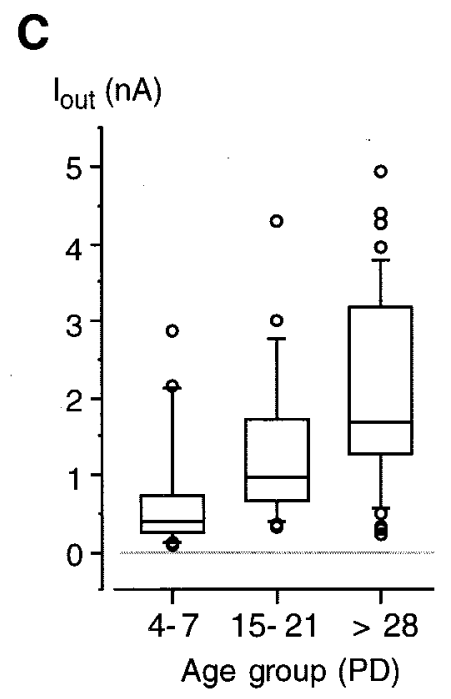

Figure 7. Voltage-gated outward currents $\left(I_{\text {out }}\right)$ in Na/OUT cells during postnatal development. $A$, Membrane currents recorded from Na/OUT cells of the vallate papilla in mice of different ages ( $P D$ 6,PD 11, and $P D$ 20). Membrane currents were elicited by a series of depolarizing pulses between $-74 \mathrm{mV}$ and $+86 \mathrm{mV}$, in $10 \mathrm{mV}$ increments, from a holding potential of $-84 \mathrm{mV}$. Voltage-gated $\mathrm{Na}^{+}$currents (downward deflections in the current records) were of similar magnitude in all three cells. On the contrary, voltage-dependent outward currents $\left(I_{\text {out }}\right.$, upward deflections in the current records) markedly increase in their magnitude during development. $P D$, Postnatal day. $B$, Current-voltage relationships of $I_{\text {out. }}$ Cells were pooled into three age groups $(P D 4-7, P D 15-21$, and $P D>28)$, and amplitude values of $I_{\text {out }}$ for each membrane potential $\left(V_{\mathrm{m}}\right)$ were averaged within each group $(n=44 / 23 / 44) . I_{\text {out }}$ amplitude was measured at the end of $30 \mathrm{msec}$ pulses. $I_{\text {out }}$ activated at approximately $-20 \mathrm{mV}$ and showed a pronounced increase during development. $C$, Amplitude distribution of $I_{\text {out. }}$. Amplitude values (evaluated at $+46 \mathrm{mV}$ and at the end of a $30 \mathrm{msec}$ voltage pulse) are displayed in the form of a box plot (see Materials and Methods for details) for three age groups (PD 4-7, PD 15-21, and PD>28). Note that both the median and the data range increase during development, indicating that there is a rise in the number of Na/OUT cells possessing sizeable $I_{\text {out }} \cdot n=41(P D 4-7)$, $23(P D 15-21), 44(P D>28)$.

similar for all three age groups. However, the outlined boxes show that the middle half of the data underwent a broadening toward larger values during developing. High $I_{\mathrm{Na}}$ values already in PD 4-7 mice could be caused by variations in the onset of maturation among taste cells (Hosley and Oakley, 1987; Cooper and Oakley, 1998), whereas low $I_{\mathrm{Na}}$ values in adult mice likely reflect the appearance of new taste cells during cell turnover (see Discussion).

We also studied $I_{\text {out }}$ in Na/OUT cells during postnatal development. $I_{\text {out }}$ is carried by $\mathrm{K}^{+}$and $\mathrm{Cl}^{-}$and is mainly responsible for the repolarization phase in gustatory action potentials and for afterpotentials (Chen et al., 1996; Herness and Sun, 1999). As 

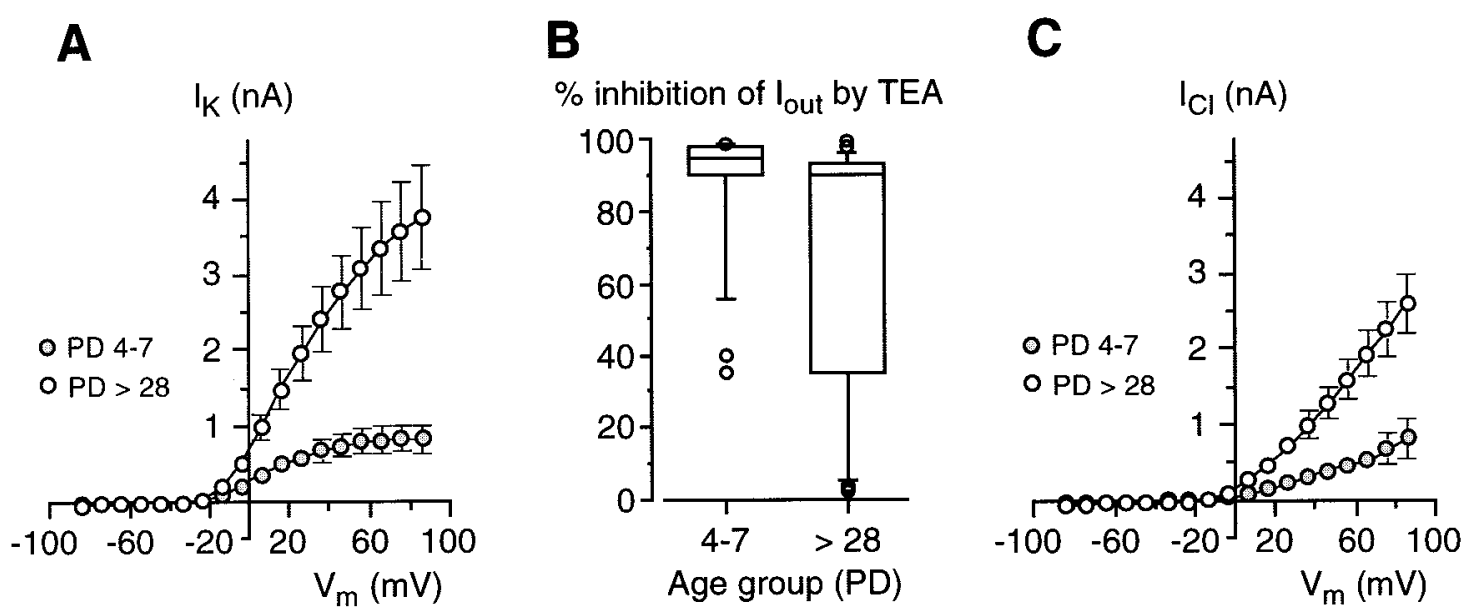

Figure 8. Voltage-dependent $\mathrm{K}^{+}$and $\mathrm{Cl}^{-}$currents $\left(I_{K}\right.$ and $I_{C l}$, respectively) in developing Na/OUT cells of the mouse vallate papilla. $A$, Currentvoltage relationships for $I_{\mathrm{K}}$ in young $(P D 4-7)$ and adult $(P D>28)$ mice. Current amplitude was measured at the end of $30 \mathrm{msec}$ voltage pulses. Amplitude values for each membrane potential $\left(V_{\mathrm{m}}\right)$ were averaged within each age group $(n=19$ for $P D 4-7 ; n=18$ for $P D>28)$. Error bars represent \pm SEM. Holding potential was $-84 \mathrm{mV}$. B, Box plot for the effect of $20 \mathrm{~mm}$ TEA on voltage-dependent outward currents $\left(I_{\text {out }}\right)$ in Na/OUT cells from young $(P D 4-7 ; n=23$ cells $)$ and adult $(P D>28 ; n=32$ cells $)$ mice. Inhibition by TEA was evaluated on currents elicited by depolarizing the membrane to $+46 \mathrm{mV}$ from a holding potential of $-84 \mathrm{mV}$. In young animals, the majority of Na/OUT cells displayed almost exclusively $I_{\mathrm{K}}$, as indicated by the position of the outlined box in the top of the graph. On the contrary, in adults a large proportion of Na/OUT cells displayed both $I_{\mathrm{K}}$ and $I_{\mathrm{Cl}}$, as indicated by the broadening of the outlined box toward the lower inhibition values. $C$, Current-voltage relationships for $I_{\mathrm{Cl}}$ in young $(P D 4-7)$ and adult $(P D>28)$ mice. Amplitude values for each membrane potential $\left(V_{\mathrm{m}}\right)$ were averaged within each age group $(n=4$ for $P D 4-7 ; n=10$ for $P D>$ 28).

reported above, the relative contribution of $\mathrm{K}^{+}$and $\mathrm{Cl}^{-}$currents to $I_{\text {out }}$ was highly variable in taste cells from adult mice. Because of this complexity, in a first series of experiments we did not attempt to distinguish the two current components, and we analyzed the outward currents as a whole. Figure $7 A$ shows representative recordings from developing Na/OUT cells. Although all of these cells displayed voltage-gated $\mathrm{Na}^{+}$currents of similar amplitude (downward deflections in the current traces), their $I_{\text {out }}$ increased significantly with the age of the animal. The increase of $I_{\text {out }}$ was also evident when the averaged $I-V$ plots were evaluated for different age groups (Fig. $7 B$ ). At a reference potential of +46 $\mathrm{mV}, I_{\text {out }}$ was $668 \pm 113(n=44)$ for PD $4-7$, whereas in adult mice $(\mathrm{PD}>28)$ it was approximately three times larger $(1971 \pm$ 214; $n=33$ ). Interestingly, $I_{\text {out }}$ activated at approximately the same voltage (approximately $-20 \mathrm{mV}$ ) for all age groups tested (Fig. $7 B$ ). The increase in $I_{\text {out }}$ was not related to an increase in cell membrane surface during development, as indicated by $C_{\mathrm{m}}$ measurements (Fig. 5). Figure $7 C$ shows the distribution of $I_{\text {out }}$ magnitude for young (PD 4-7), preweaning (PD 15-21), and adult $(\mathrm{PD}>28)$ mice. These plots clearly indicate that there was an increase in the number of Na/OUT cells possessing large $I_{\text {out }}$. Interestingly, the lowest value of $I_{\text {out }}$ was similar for all ages. This was likely because of the appearance of new taste cells during cell turnover (see Discussion).

To establish whether the rise in $I_{\text {out }}$ was caused by a specific component of this current (namely, the $\mathrm{K}^{+}$or $\mathrm{Cl}^{-}$current), we performed a series of experiments aimed at evaluating the effect of TEA on $I_{\text {out }}$ during development. A first comparison was made between cells in which $20 \mathrm{~mm}$ TEA blocked the outward currents for $>80 \%$, that is, between cells expressing almost exclusively voltage-dependent $\mathrm{K}^{+}$currents $\left(I_{\mathrm{K}}\right)$. As shown by Figure $8 A, I_{\mathrm{K}}$ increased conspicuously during development. At a reference potential of $+46 \mathrm{mV}, I_{\mathrm{K}}$ was $742 \pm 156 \mathrm{pA}(n=19)$ for PD 4-7 mice, whereas in adult mice $(\mathrm{PD}>28)$ it was approximately four times larger $(2763 \pm 501 \mathrm{pA} ; n=18)$. In addition to $I_{\mathrm{K}}$, chloride currents $\left(I_{\mathrm{Cl}}\right)$ also were affected by development. As indicated by the box plot in Figure $8 B$, the occurrence of cells in which TEA only partially blocked $I_{\text {out }}$ was larger in the adults than in mouse pups. The currents remaining during TEA application were carried by chloride ions as indicated by their sensitivity to DIDS; that is, the combination of TEA and DIDS completely abolished the outward current (data not shown). In young animals, the majority of taste cells $(\sim 83 \%$; 19 of 23 cells $)$ possessed almost exclusively $I_{\mathrm{K}}(\mathrm{PD} 4-7$ ) (Fig. $8 B$ ). On the contrary, in the adults a large proportion of Na/OUT cells (10 of 32 cells; $~ 31 \%)$ had $I_{\mathrm{Cl}}$ $(\mathrm{PD}>28)$ (Fig. $8 B$ ) in addition to $I_{\mathrm{K}}$. Interestingly, a few cells showed almost exclusively $I_{\mathrm{C} 1}\left(\sim 13 \% ; 4\right.$ of 32 cells). Thus, $I_{\mathrm{C} 1}$ seems to be expressed later than $I_{\mathrm{K}}$ during development. To evaluate the magnitude of chloride currents, we measured $I_{\text {out }}$ during TEA block. Figure $8 C$ shows the $I-V$ plots for $I_{\mathrm{C} 1}$ in both young $(\mathrm{PD} 4-7)$ and adult $(\mathrm{PD}>28)$ mice. At a membrane voltage of $+46 \mathrm{mV}, I_{\mathrm{Cl}}$ was $396 \pm 90 \mathrm{pA}(n=4)$ in young mice, and $1274 \pm 213 \mathrm{pA}(n=10)$ in adults.

$I_{\mathrm{K}}$ typically exhibited a slow inactivation during $400 \mathrm{msec}$ depolarization pulses in both mouse pups and adults (Fig. 9A), whereas chloride currents did not inactivate (data not shown). We evaluated inactivation properties of $I_{\mathrm{K}}$ during development by measuring the ratio between the current amplitude at $400 \mathrm{msec}$ and the current peak. At $+46 \mathrm{mV}$, this ratio was $0.63 \pm 0.05(n=$ $15)$ and $0.74 \pm 0.03(n=9)$ in mouse pups (PD 4-7) and adults $(\mathrm{PD}>28)$, respectively. These values were not statistically different. Figure $9 B$ shows the effect of holding potential $\left(V_{\mathrm{h}}\right)$ on the inactivation of $\mathrm{K}^{+}$currents in a Na/OUT cell of adult mouse: currents were totally abolished by depolarizing the cell membrane at approximately $-24 \mathrm{mV}$. Similar findings were also observed in mouse pups (data not shown).

In addition to $I_{\mathrm{K}}$ and $I_{\mathrm{Cl}}, \mathrm{Ca}^{2+}$-dependent $\mathrm{K}^{+}$currents and $\mathrm{Ca}^{2+}$-dependent $\mathrm{Cl}^{-}$currents have been described in rat taste cells (Chen et al., 1996; Herness and Sun, 1999). The application of a $\mathrm{Ca}^{2+}$-free Tyrode solution (containing $3 \mathrm{mM} \mathrm{Mg}^{2+}$ ) did not 
A
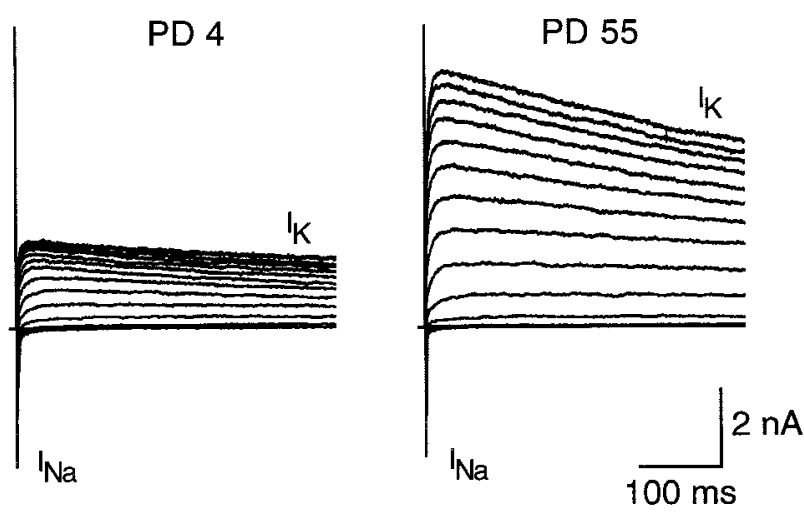

B
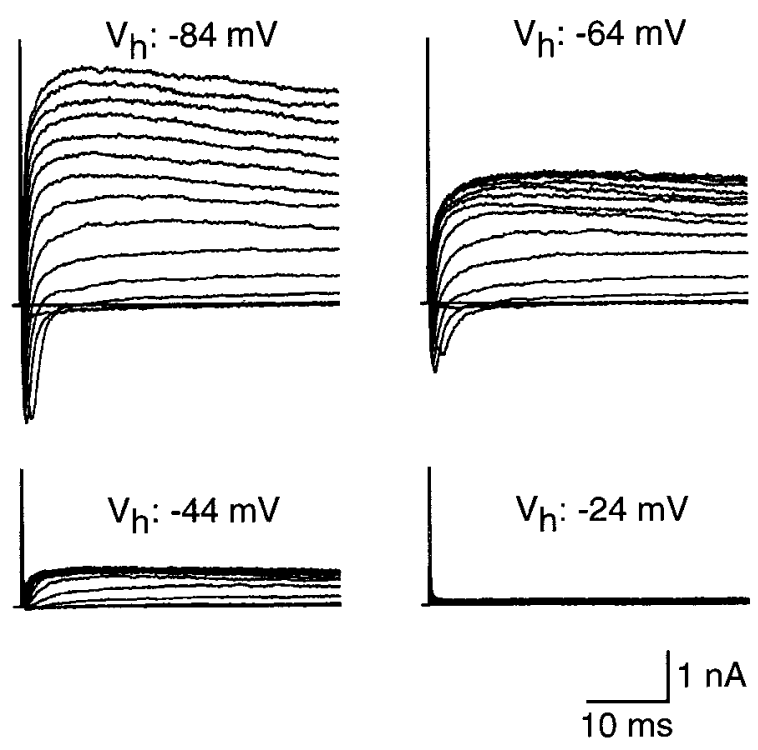

Figure 9. Inactivation of voltage-dependent $\mathrm{K}^{+}$current $\left(I_{\mathrm{K}}\right)$ in Na/OUT cells. $A, I_{\mathrm{K}}$ recorded from cells in mice of different ages (PD 4 and $\left.P D 55\right)$. $P D$, Postnatal day. Currents were elicited by a series of $400 \mathrm{msec}$ depolarizing voltage pulses between $-74 \mathrm{mV}$ and $+86 \mathrm{mV}$, in $10 \mathrm{mV}$ increments, from a holding potential of $-84 \mathrm{mV}$. Note the decrease in $I_{\mathrm{K}}$ amplitude during prolonged voltage pulses (inactivation). $I_{\mathrm{Na}}$, Voltagegated $\mathrm{Na}^{+}$currents. $B$, Effect of holding potential $\left(V_{\mathrm{h}}\right)$ on the inactivation of $I_{\mathrm{K}}$ in an Na/OUT cell from the vallate papilla of a 50-d-old mouse. $\mathrm{K}^{+}$ currents (upward deflections in the records) were elicited by a series of depolarizing voltage pulses in $10 \mathrm{mV}$ increments from different holding potentials $\left(V_{\mathrm{h}}:-84,-64,-44,-24 \mathrm{mV}\right)$. All records are from the same cell. Downward deflections in the records at $V_{\mathrm{h}}=-84 \mathrm{mV}$ and $-64 \mathrm{mV}$ represent voltage-dependent $\mathrm{Na}^{+}$currents.

affect the outward currents in mouse Na/OUT cells $(n=4$; data not shown). This result suggested that $\mathrm{Ca}^{2+}$-dependent currents did not contribute substantially to the outward currents. A further analysis of possible $\mathrm{Ca}^{2+}$-dependent components of $I_{\text {out }}$ was beyond the scope of our study.

\section{Action potentials in developing taste cells}

The remarkable increase in the magnitude of repolarizing currents $\left(I_{\text {out }}\right)$, particularly $I_{\mathrm{K}}$, was expected to have a profound effect on excitability. Because such currents tend to counteract the depolarizing action of $\mathrm{Na}^{+}$currents, they modulate the shape of action potentials and the firing pattern in excitable cells (Hille,
2001). Thus, we examined action potential waveform in young (PD 4-7), preweaning (PD 15-21), and adult $(\mathrm{PD}>28)$ mice using whole-cell current-clamp recordings. Because in mice pups (PD 4-7) the occurrence of $I_{\mathrm{Cl}}$ was very low (Fig. $8 B$ ), we studied action potential waveforms only in $\mathrm{Na} / \mathrm{OUT}$ cells possessing predominantly $I_{\mathrm{K}}$. To correlate changes in action potential waveforms with the ionic currents underlying them, action potentials were elicited by injecting depolarizing current from a membrane potential of approximately $-80 \mathrm{mV}$, that is, close to the holding potential from which voltage-dependent currents were produced. Figure $10 \mathrm{~A}$ shows representative recordings of action potential waveforms in $\mathrm{Na} / \mathrm{OUT}$ cells from animals of different ages. These cells were electrically excitable in young animals, but in the majority of them action potential waveforms were distinctively different from those produced in adults. In particular, action potential duration was typically larger in young animals than in adults (Fig. $10 A$, compare $P D 4$ with $P D$ 65). Although the duration of action potential is often used to characterize its waveform (Chen et al., 1996; Gao and Ziskind-Conhaim, 1998), we found it more convenient to evaluate the action potential maximum rates of rise $\left(d V / d t+\right.$, depending on $\left.I_{\mathrm{Na}}\right)$ and repolarization $\left(d V / d t-\right.$, depending on $\left.I_{\mathrm{K}}\right)$ in developing taste cells. Figure $10 B$ (left) shows the results of such an analysis for three age groups (PD 4-7, PD 15-21, PD > 28). $d V / d t+$ increased postnatally, although the differences were not statistically significant. This result was consistent with the observation that during development there was an increase in the number of Na/OUT cells with sizeable $I_{\mathrm{Na}}$, although the magnitude range for this current did not change (Fig. $6 B$ ). On the contrary, $d V / d t-$ became significantly more negative during development (Fig. 10B, right), consistent with the large increase in $I_{\mathrm{K}}$ (Fig. $8 A$ ). Thus, the action potential waveforms in developing Na/OUT cells (Fig. 10 $A$ ) were markedly affected by the increase in magnitude of repolarizing currents.

We then analyzed the firing behavior of developing Na/OUT cells. In young animals (PD $4-7$ ), only 4 of 18 cells ( $22 \%$ of tested cells) were capable of repetitive firing (at least two action potentials per discharge) after stimulation with a long depolarizing pulse. On the contrary, in adults, a complex pattern of repetitive firing could be evoked in 12 of 23 cells $(\sim 52 \%)$ by longlasting depolarizations. Figure $10 C$ shows the firing pattern in the same $\mathrm{Na} / \mathrm{OUT}$ cells of Figure $10 A$. These findings were also consistent with the significant increase in the magnitude of $I_{\mathrm{K}}$ during development. In conclusion, the fourfold postnatal increase of $I_{\mathrm{K}}$ density resulted in a higher speed of repolarization of action potential and in an increased firing capability by Na/OUT cells.

\section{$\alpha$-Gustducin immunoreactivity during postnatal development}

To establish whether electrophysiological changes in mouse taste buds occurred concomitantly with variations in other properties of taste cells, such as the expression of specific proteins involved in the early events of sensory transduction, we used immunofluorescence to quantify the distribution of gustducin immunoreactivity (IR). Gustducin is the $\alpha$-subunit of a G-protein considered to be a potent marker of chemosensitive cells (Boughter et al., 1997; Sbarbati et al., 1999).

We first evaluated the number of taste buds containing gustducin-positive cells during postnatal development. As shown in Figure $11 A$, gustducin-IR was distributed throughout the cytoplasm of taste cells (Boughter et al., 1997; Cho et al., 1998; 

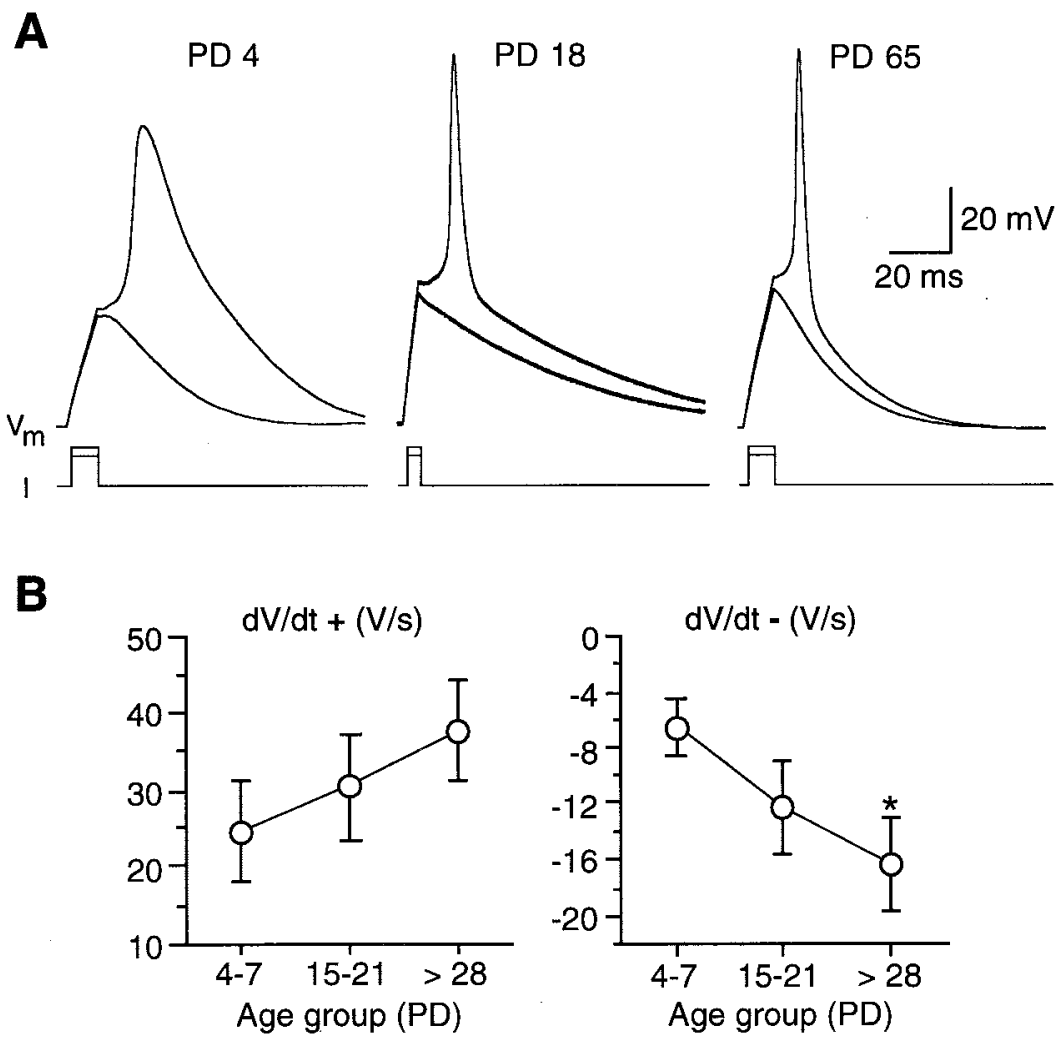

Figure 10. Action potentials recorded from Na/OUT cells of the mouse vallate papilla. $A$, Action potential waveforms in Na/OUT cells from young ( $P D$ 4 ), preweaning (PD 18), and adult (PD 65) mice. Cell membrane was held at approximately $-80 \mathrm{mV}$, and two depolarizing current pulses were injected (13 and 14 pA for $P D 4 ; 28$ and 30 pA for $P D 18 ; 16$ and 17 for $P D$ 65). The first pulse was subthreshold and failed to elicit action potentials. $B$, Action potential maximum rates of rise $(d V / d t+)$ and repolarization $(d V / d t-)$ in Na/OUT cells during development. Cells were pooled into three age groups $(P D$ 4-7, $P D$ 15-21, and $P D>28)$. $d V / d t+$ and $d V / d t-$ values were averaged within each group $(n=18 / 12 / 24)$. Error bars represent \pm SEM. Asterisk indicates significant difference. $P D$, Postnatal day. $C$, Firing behavior of the Na/OUT cells shown in $A$. Action potential discharges were elicited by injecting long depolarizing current pulses (1.6 and $1.8 \mathrm{pA}$ for $P D 4 ; 2.4$ and $3.2 \mathrm{pA}$ for $P D 18 ; 5$ and $6 \mathrm{pA}$ for $P D$ 65). The first pulse was subthreshold, whereas the second one elicited action potentials, although the firing pattern was different among cells. In PD 4 cells, only one action potential could be evoked, whereas in PD 65 cells a complex pattern of repetitive firing appeared. In PD 18 cells, an incipient action potential was evoked after the first, full-size spike. $V_{\mathrm{m}}$, Membrane potential. I, Current injected.

Sbarbati et al., 1999; Yang et al., 2000). Quantitative analysis of gustducin expression at different postnatal ages revealed a significant increase in the number of immunolabeled taste buds from PD 4 to PD 14. By PD 14, the number of gustducin-positive buds reached the value found in adults $(\sim 120)$ (Fig. $11 B)$. In addition, we found that the number of gustducin-positive cells in single taste buds (Fig. 12A) increased markedly during the first 2 weeks after birth and reached the value found in the adult $(\sim 10$ cells per bud) by PD 14 (Fig. 12B). Thus, our findings indicated that the chemotransduction system involving $\alpha$-gustducin developed rapidly during the first 2 postnatal weeks (Figs. 11, 12). On the contrary, membrane excitability matured more slowly in Na/OUT cells (Fig. 7). In addition, the abrupt rise in the number of leaky cells among patched cells occurred after the gustducin expression had reached its maximum (compare Fig. 4 with Figs. 11 and 12).

\section{DISCUSSION}

\section{Development of membrane excitability in putative taste sensory cells}

In this study, we used patch-clamp recordings to examine the membrane properties of mouse vallate taste cells during postnatal development. The main finding is that a specific functional subset of taste cells (the Na/OUT cells, thought to be sensory) undergoes an electrophysiological differentiation after birth. Specifi- cally, we found that the magnitude of voltage-dependent outward currents $\left(I_{\text {out }}\right.$, repolarizing currents composed of $I_{\mathrm{K}}$ and $I_{\mathrm{Cl}}$ ) increased approximately three times in 5 weeks. This increase was not dependent on the cell surface area. In other words, it was an actual increase in current density. The pharmacological analysis allowed us to establish that the rise of $I_{\text {out }}$ was caused by both components of this current, namely, $I_{\mathrm{K}}$ and $I_{\mathrm{C} 1}$ (Fig. 13). Interestingly, the development of $I_{\mathrm{K}}$ seemed to precede the appearance of $I_{\mathrm{Cl}}$. Consistent with the significant postnatal increase in $I_{\mathrm{K}}$, we found that $\mathrm{Na} / \mathrm{OUT}$ cells became more excitable, as indicated by the characteristics of their action potentials and firing capability. Indeed, voltage-dependent potassium channels permit excitation because they do not interfere with the rise to the threshold for action potential firing, and they actively promote recovery and rapid refiring. The "resting" potential of Na/OUT cells, estimated as $V_{0}$, becomes more negative during development, and this is also consistent with the increased excitability of $\mathrm{Na} / \mathrm{OUT}$ during development. The postnatal increase of $I_{\mathrm{K}}$ and $I_{\mathrm{Cl}}$ might reflect an increase in the number of $\mathrm{K}^{+}$and $\mathrm{Cl}^{-}$ channels, assuming that single-channel conductances and their open probability remain unchanged. Indeed, inactivation properties of $I_{\mathrm{K}}$ did not change significantly during development.

Unlike our findings, Kossel et al. (1997) established that voltage-gated outward currents undergo little if any changes dur- 

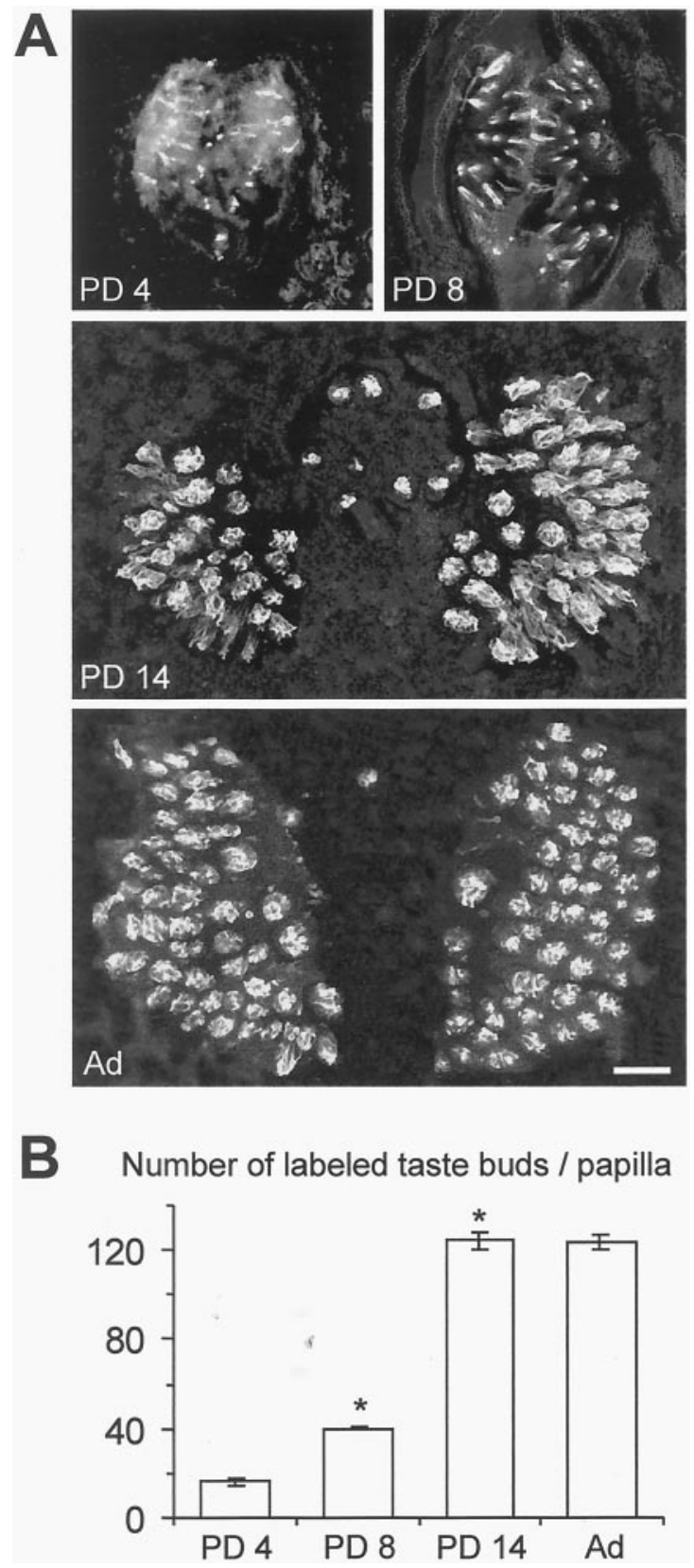

Figure 11. Gustducin immunoreactivity in developing vallate papillae of the mouse. $A$, Confocal images ( 1 and $3 \mu \mathrm{m}$ thick at PD 4-8 and PD 14 -adult, respectively) through whole-mount preparations of the vallate papilla from animals at different ages showing gustducin immunoreactivity visualized with FITC-conjugated secondary antibodies. Gustducinpositive taste buds are clearly distinguishable at all ages. $B$, Quantitative evaluation of the number of taste buds containing gustducin-positive cells during postnatal development. Mean number $( \pm \mathrm{SEM})$ of gustducinimmunoreactive taste buds from five animals for each age. This number significantly increased from PD 4 to PD $14(p<0.001)$, with no further changes until adulthood. Asterisks indicate significant differences. PD, Postnatal day.

ing postnatal development in taste cells from rat fungiform papillae. Thus, the maturation processes affecting the functional properties of taste cells during postnatal development can differ considerably, even in related mammalian species such as rat and mouse. These findings add further complexity to the physiology of the peripheral taste system and could be related to the variety of transduction mechanisms adopted by different vertebrate species (Lindemann, 1996).

Several questions about membrane excitability in developing mouse taste cells remain to be answered. Among other things, the development of $I_{\mathrm{Cl}}$ and its impact on membrane firing capabilities represents one of the future directions of our research. Indeed, the occurrence of some taste cells possessing almost exclusively $I_{\mathrm{C} 1}$ in the adults suggests an electrophysiological diversification among Na/OUT cells during development (Fig. 13). It is interesting to note that in rat vallate taste cells chloride currents represent only a small portion of the outward current (Herness and Sun, 1999), whereas in mouse vallate taste buds some cells exhibit large $I_{\mathrm{Cl}}$. It is likely that these differences may have a profound effect on the transduction capabilities of taste cells in mouse as compared with rat.

Our data indicate that variations in membrane excitability occurred during several days after birth (at least 4 weeks), whereas gustducin-IR matured quite rapidly in mouse taste buds ( $\sim 2$ weeks). Thus, the expression of specific components of transduction mechanisms, such as voltage-dependent ion channels and G-proteins, takes place on different time scales during postnatal development in the mouse.

\section{Membrane excitability and taste transduction}

Changes in the membrane excitability of taste cells may have a profound impact on the functioning of taste buds during development. Several lines of evidence suggest that taste buds are complex chemosensory structures. For example, not all chemosensitive cells are innervated (Ohtubo et al., 2001), and lateral interactions mediated by gap junctions (electrical synapses) have been documented between taste cells (Bigiani and Roper, 1993, 1995). Accordingly, the sensory output to the nerve terminals most likely represents the integrated activity of a population of cells rather than the activity of single, separate cells (Roper, 1989, 1993). It is then tempting to speculate that the increase in the number of spiking cells among Na/OUT cells could imply variation in the sensitivity of the taste transduction system during development, because firing might provide a significant boost in signaling inside taste buds. In addition, it is well established that certain transduction mechanisms involve the modulation of voltage-dependent $\mathrm{K}^{+}$currents (Cummings et al., 1996; Gilbertson et al., 1997). Finally, $\mathrm{Cl}^{-}$currents seem to play a role in sensory adaptation and in efferent control by nerve terminals (Taylor and Roper, 1994; Herness and Sun, 1999). In conclusion, the increased magnitude of repolarizing currents $\left(I_{\mathrm{K}}\right.$ and $\left.I_{\mathrm{Cl}}\right)$ during development is likely to affect markedly the transduction properties of mouse taste cells.

\section{Functional populations of taste cells during postnatal development}

In addition to membrane excitability changes in putative sensory cells, we found a functional rearrangement of taste cell subsets in the vallate papilla during postnatal development. In particular, the frequency of the so-called leaky cells among the patched cells increases noticeably in the beginning of the third postnatal week. This change may actually reflect the presence of a larger number of leaky cells in taste buds. It has been suggested recently that leaky cells represent glia-like elements (Bigiani, 2001). Thus, the appearance of these cells during postnatal development could be related to the increased excitability of putative sensory cells (the $\mathrm{Na} / \mathrm{OUT}$ cells). Ionic fluxes associated with action potential firing are expected to increase, and this may require a more efficient 
A
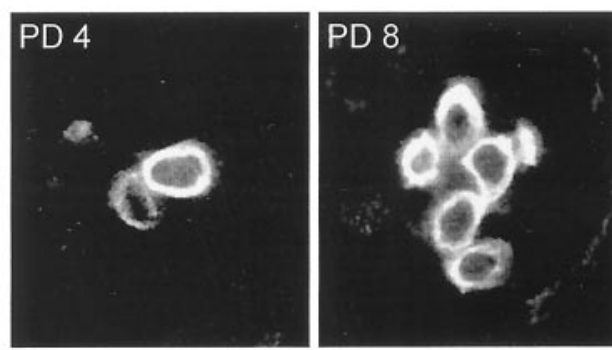
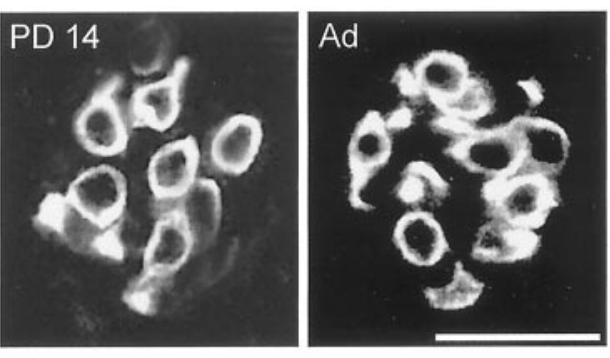

B

Number of labeled cells / taste bud

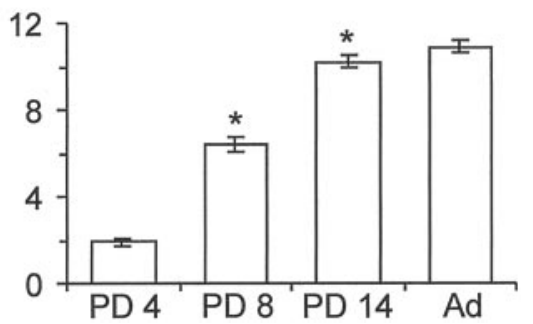

Figure 12. Gustducin-immunoreactive taste cells in developing taste buds of the mouse vallate papillae. $A$, Confocal images ( 0.5 and $1 \mu \mathrm{m}$ thick at PD 4-8 and PD 14-adult, respectively) through taste buds in whole-mount preparations from animals of different ages showing gustducin immunoreactivity visualized with FITC-conjugated secondary antibodies. Gustducin immunoreactivity appears to be distributed throughout the cytoplasm of labeled cells. $B$, Quantitative evaluation of the number of gustducin-positive cells per each taste bud during postnatal development. Mean number ( \pm SEM) of gustducin-immunoreactive cells from 30-40 measurements for each age. This number significantly increased from PD 4 to PD 14 ( $p<0.001$ ), with no further changes until adulthood. Asterisks indicate significant differences. $P D$, Postnatal day.

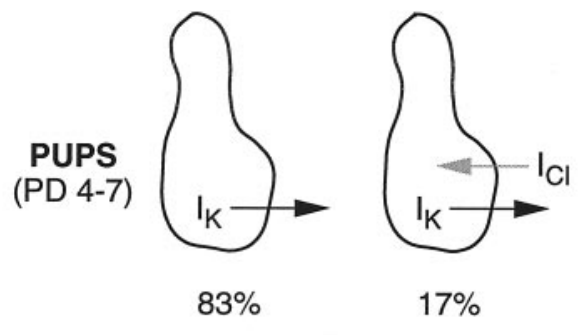

ADULTS $(\mathrm{PD}>28)$

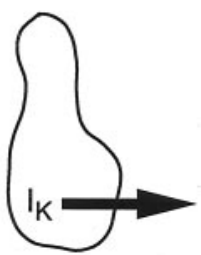

$56 \%$

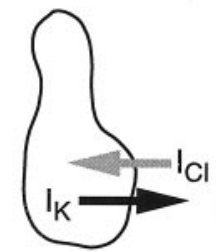

$31 \%$

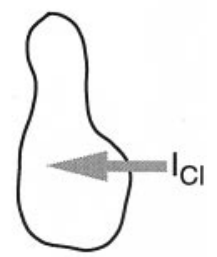

$13 \%$
Figure 13. Schematic overview of the development of voltage-dependent $\mathrm{K}^{+}$and $\mathrm{Cl}^{-}$currents $\left(I_{\mathrm{K}}\right.$ and $I_{\mathrm{Cl}}$, respectively) in Na/OUT cells of the mouse vallate papilla. Line thickness is proportional to the average amplitude of ion currents in taste cells for each age group. Percent values refer to the relative occurrence among patched cells. $P D$, Postnatal day.

"glia-like system" inside taste buds to control ion concentrations, most notably $\mathrm{K}^{+}$concentration, in the extracellular space.

In addition to putative sensory cells (Na/OUT cells) and glialike cells (leaky cells), we identified a third subset of taste cells in the vallate papilla of adult mouse. These cells, called OUT cells, possessed only voltage-gated outward currents carried by $\mathrm{K}^{+}$and were not electrically excitable (data not shown). OUT cells occurred at all ages. Their specific role in taste bud physiology is unknown. According to work on Necturus taste cells (Bigiani and Roper, 1993; Delay et al., 1994; Mackay-Sim et al., 1996), unexcitable cells endowed with potassium current might represent putative stem basal cells or a transitional state during the continuous turnover of taste sensory cells (see below).

\section{Postnatal development and cell turnover}

Adult taste buds consist of a renewing population of neuroepithelial cells (Roper, 1989). The life span of taste cells is $\sim 10 \mathrm{~d}$ in fungiform and vallate papillae of the adult rat (Beidler and
Smallman, 1965; Farbman, 1980). Many mature taste cells are electrically excitable and are thought to develop from unexcitable, undifferentiated cells within the taste buds (Delay et al., 1986, 1994). As a consequence, variations in the membrane properties of taste cells in adult animals are expected to occur. Strong support for this hypothesis has been provided by findings on the electrophysiological properties of Necturus taste cells (MackaySim et al., 1996). Our results on the taste cells of the adult mouse are consistent with cell turnover. For example, the amplitude of $I_{\mathrm{Na}}$ and $I_{\text {out }}$ is quite variable in "adult" taste cells. Moreover, as indicated by the error bars in Figure $10 \mathrm{~B}$, variability in the action potential waveform do occur in the taste cells of adult mice. This is consistent also with previous studies reporting different types of action potentials (long and short) in rat taste cells (Béhé et al., 1990; Chen et al., 1996).

An obvious issue is whether changes in electrophysiological properties of mouse taste cells during postnatal development are caused by the normal cell turnover or by other developmental processes switched on before adulthood. Recent studies on taste cell proliferation have revealed lower rates of cell turnover in newborn and juvenile (PD 0-21) rats compared with adults (Hendricks and Hill, 1999). This finding suggests that taste cells might have a longer life span in juveniles than in adults. It is then tempting to speculate that the maturation of $I_{\mathrm{K}}$ and $I_{\mathrm{C} 1}$ that occurs over several weeks during postnatal development could reflect a slow cell turnover. Consistent with this is the observation that the lowest value of $I_{\text {out }}$ distribution does not change during postnatal development. However, this interpretation cannot explain adequately the abrupt rise in the occurrence of leaky cells during the third postnatal week. Leaky cells could result from a conversion of the membrane properties of $\mathrm{Na} / \mathrm{OUT}$ cells (or OUT cells). Recently it has been shown that protein kinase A (PKA) mediates the reversible conversion of potassium leak into a voltage-dependent channel in hippocampal neurons (Bockenhauer et al., 2001). PKA is expressed in taste cells (Avenet et al., 1988). Thus, PKA regulation in developing Na/OUT cells (or OUT cells) could induce changes in their membrane properties, leading to the appearance of leaky cells. Also, the rapid development of gustducin-IR during the first 2 postnatal weeks is not explained satisfactorily by a slow cell turnover. Therefore, it is likely that in addition to cell turnover, other age-related processes take place during postnatal development of mouse taste cells. 


\section{REFERENCES}

Akabas MH, Dodd J, Al-Awqati Q (1990) Identification of electrophysiologically distinct subpopulations of rat taste cells. J Membr Biol 114:71-78.

Avenet P, Lindemann B (1991) Noninvasive recording of receptor cell action potentials and sustained currents from single taste buds maintained in the tongue: the response to mucosal $\mathrm{NaCl}$ and amiloride. $\mathrm{J}$ Membr Biol 124:33-41.

Avenet P, Hofmann F, Lindemann B (1988) Transduction in taste receptor cells requires cAMP-dependent protein kinase. Nature 331:351-354.

Baraban SC, Lothman EW (1994) Voltage-activated potassium currents in acutely dissociated hippocampal dentate gyrus neurons from neonatal rats. Dev Brain Res 81:309-313.

Barry PH, Lynch JW (1991) Liquid junction potentials and small cell effects in patch clamp analysis. J Membr Biol 121:101-117.

Béhé B, DeSimone JA, Avenet P, Lindemann B (1990) Membrane currents in taste cells of the rat fungiform papilla: evidence for two types of $\mathrm{Ca}$ currents and inhibition of K currents by saccharin. J Gen Physiol 96:1061-1084.

Beidler LM, Smallman R (1965) Renewal of cells within taste buds. J Cell Biol 27:263-272.

Bigiani A (2001) Mouse taste cells with glia-like membrane properties. J Neurophysiol 85:1552-1560.

Bigiani A, Roper SD (1993) Identification of electrophysiologically distinct cell subpopulations in Necturus taste buds. J Gen Physiol 102:143-170.

Bigiani A, Roper SD (1995) Estimation of the junctional resistance between electrically coupled receptor cells in Necturus taste buds. J Gen Physiol 106:705-725.

Bigiani A, Kim DJ, Roper SD (1996) Membrane properties and cell ultrastructure of taste receptor cells in Necturus lingual slices. J Neurophysiol 75:1944-1956.

Bockenhauer D, Zilberberg N, Goldstein SAN (2001) KCNK2: reversible conversion of hippocampal potassium leak into a voltagedependent channel Nat Neurosci 4:486-491.

Boughter Jr JD, Pumplin DW, Yu C, Christy RC, Smith DV (1997) Differential expression of $\alpha$-gustducin in taste bud populations of the rat and hamster. J Neurosci 17:2852-2858.

Castle NA, Haylett DG, Jenkinson DH (1989) Toxins in the characterization of potassium channels. Trends Neurosci 12:59-65.

Chen Y, Sun XD, Herness S (1996) Characteristics of action potentials and their underlying outward currents in rat taste receptor cells. J Neurophysiol 75:820-831.

Cho YK, Farbman AI, Smith DV (1998) The timing of $\alpha$-gustducin expression during cell renewal in rat vallate taste buds. Chem Senses 23:735-742.

Cooper D, Oakley B (1998) Functional redundancy and gustatory development in bdnf null mutant mice. Dev Brain Res 105:79-84.

Cummings TA, Powell J, Kinnamon SC (1993) Sweet taste transduction in hamster taste cells: evidence for the role of cyclic nucleotides. J Neurophysiol 70:2326-2336.

Cummings TA, Daniels C, Kinnamon SC (1996) Sweet taste transduction in hamster: sweeteners and cyclic nucleotides depolarize taste cells by reducing a $\mathrm{K}^{+}$current. J Neurophysiol 75:1256-1263.

Delay RJ, Kinnamon JC, Roper SD (1986) Ultrastructure of mouse vallate taste buds: II. Cell types and cell lineage. J Comp Neurol 253:242-252.

Delay RJ, Mackay-Sim A, Roper SD (1994) Membrane properties of two types of basal cells in Necturus taste buds. J Neurosci 14:6132-6143.

Farbman AI (1980) Renewal of taste bud cells in rat circumvallate papillae. Cell Tissue Kinet 13:349-357.

Furue H, Yoshii K (1997) In situ tight-seal recordings of taste substanceelicited action currents and voltage-gated Ba currents from single taste bud cells in the peeled epithelium of mouse tongue. Brain Res 776:133-139.

Gao B-X, Ziskind-Conhaim L (1998) Development of ionic currents underlying changes in action potential waveforms in rat spinal motoneurons. J Neurophysiol 80:3047-3061.

Gilbertson TA, Avenet A, Kinnamon SC, Roper SD (1992) Proton cur- rents through amiloride-sensitive $\mathrm{Na}$ channels in hamster taste cells. J Gen Physiol 100:803-824.

Gilbertson TA, Fontenot DT, Liu L, Zhang H, Monroe WT (1997) Fatty acid modulation of $\mathrm{K}^{+}$channels in taste receptor cells: gustatory cues for dietary fat. Am J Physiol 272:C1203-C1210.

Hamill OP, Marty A, Neher E, Sakmann B, Sigworth FJ (1981) Improved patch-clamp techniques for high-resolution current recording from cells and cell-free membrane patches. Pflügers Arch 391:85-100.

Hendricks SJ, Hill DL (1999) Proliferation of taste receptor cells is lower during early postnatal rat development as compared with adults. Chem Senses 24:587.

Herness MS, Gilbertson TA (1999) Cellular mechanisms of taste transduction. Annu Rev Physiol 61:873-900.

Herness MS, Sun X-D (1999) Characterization of chloride currents and their noradrenergic modulation in rat taste receptor cells. J Neurophysiol 82:260-271.

Hille B (2001) Ionic channels of excitable membranes. Sunderland, MA: Sinauer.

Hosley MA, Oakley B (1987) Postnatal development of the vallate papilla and taste buds in rats. Anat Rec 218:216-222.

Kim D-J, Roper SD (1995) Localization of serotonin in taste buds: a comparative study in four vertebrates. J Comp Neurol 353:364-370.

Kinnamon SC, Roper SD (1987) Passive and active membrane properties of mudpuppy taste receptor cells. J Physiol (Lond) 383:601-614.

Kossel AH, McPheeters M, Lin W, Kinnamon SC (1997) Development of membrane properties in taste cells of fungiform papillae: functiona evidence for early presence of amiloride-sensitive sodium channels J Neurosci 17:9634-9641.

Kros CJ, Ruppersberg JP, Rüsch A (1998) Expression of a potassium current in inner hair cells during development of hearing in mice. Nature 394:281-284

Lindemann B (1996) Taste reception. Physiol Rev 76:719-766.

Mackay-Sim A, Delay RJ, Roper SD, Kinnamon SC (1996) Development of voltage-dependent currents in taste receptor cells. J Comp Neurol 365:278-288.

Ming D, Ninomiya Y, Margolskee RF (1999) Blocking taste receptor activation of gustducin inhibits gustatory responses to bitter compounds. Proc Natl Acad Sci USA 96:9903-9908.

Mistretta CM, Hill DL (1995) Development of the taste system: basic neurobiology. In: Handbook of olfaction and gustation (Doty RL, ed), pp 635-668. New York: Marcel Dekker.

Neher E (1992) Correction for liquid junction potentials in patch clamp experiments. Methods Enzymol 207:123-131.

Nolte C, Martini R (1992) Immunocytochemical localization of the L1 and N-CAM cell adhesion molecules and their shared carbohydrate epitope L2/HNK-1 in the developing and differentiated gustatory papillae of the mouse tongue. J Neurocytol 21:19-33.

Ohtubo Y, Suemitsu T, Shiobara S, Matsumoto T, Kumazawa T, Yoshii K (2001) Optical recordings of taste responses from fungiform papillae of mouse in situ. J Physiol (Lond) 530:287-293.

Roper S (1983) Regenerative impulses in taste cells. Science 220:1311-1312.

Roper SD (1989) The cell biology of vertebrate taste receptors. Annu Rev Neurosci 12:329-353.

Roper SD (1993) Synaptic interactions in taste buds. In: Mechanisms of taste transduction (Simon SA, Roper SD, eds), pp 275-293. Boca Raton, FL: CRC.

Rudy B (1988) Diversity and ubiquity of K channels. Neuroscience 25:729-749.

Sbarbati A, Crescimanno C, Bernardi P, Osculati F (1999) $\alpha$-Gustducinimmunoreactive solitary chemosensory cells in the developing chemoreceptorial epithelium of the rat vallate papilla. Chem Senses 24:469-472.

Stewart RE, DeSimone JA, Hill DL (1997) New perspectives in gustatory physiology: transduction, development, and plasticity. Am J Physiol 272:C1-C26.

Taylor R, Roper S (1994) $\mathrm{Ca}^{2+}$-dependent $\mathrm{Cl}^{-}$conductance in taste cells from Necturus. J Neurophysiol 72:475-478.

Wong GT, Gannon KS, Margolskee RF (1996) Transduction of bitter and sweet taste by gustducin. Nature 381:796-800.

Yang R, Tabata S, Crowley HH, Margolskee RF, Kinnamon JC (2000) Ultrastructural localization of gustducin immunoreactivity in microvilli of type II taste cells in the rat. J Comp Neurol 425:139-151. 